\title{
Self-compassion dan Motivasi Berprestasi pada Remaja yang Aktif di Klub Bulu Tangkis
}

\author{
Clara Moningka ${ }^{1}$, Yuzi Wiraayu Putri ${ }^{2}$ \\ 1, 2 Departemen Psikologi, Universitas Pembangunan Jaya \\ Tangerang Selatan, Banten 15413, Indonesia \\ clara.moningka@upj.ac.id \\ yuzi.wiraayu@yahoo.com
}

Received 4 February 2021, Revised 16 February 2021, Accepted 4 March 2021

\begin{abstract}
The purpose of this study was to find the effect of self-compassion to achievement motivation on adolescents who are active in in badminton club " $X$ ". This study used Selfcompassion Scale (SCS) developed by Neff and Achievement Motivation developed by Lang and Fries to measure self-compassion and achievement motivation. This study used quantitative methods with linear regression. The respondents of this research are 85 member of the badminton Club in Jakarta. The result showed that self-compassion and hope of success had a positive correlation $(r=.297, p=.00)$ and self-compassion contributes $8.8 \%$ to hope of success $R^{2=} .088, F$ $=28.857, p<.05)$, while self-compassion and fear of failure had a negative correlation $(r=-.508$, $p=.00)$ and self-compassion contributes $25.8 \%$ to fear of failure $\left(R^{2}=.258, F=8.006, p=.00\right)$.
\end{abstract}

Keywords: self-compassion, hope of success, fear of failure, adolescents, badminton

\begin{abstract}
Abstrak - Penelitian ini bertujuan untuk mengetahui kontribusi self-compassion terhadap motivasi berprestasi pada remaja yang aktif di klub bulu tangkis. Penelitian ini menggunakan SelfCompassion Scale (SCS) yang dikembangkan oleh Neff dan Achievement Motivation Scale (SCS) yang dikembangkan oleh Lang dan Fries untuk mengukur self-compassion dan motivasi berprestasi. Penelitian ini menggunakan metode kuantitatif dengan analisis regresi linear. Partisipan pada penelitian ini adalah 85 remaja anggota klub bulu tangkis di Jakarta. Hasil analisis data menunjukkan bahwa self-compassion dan hope of success berkorelasi positif $(\mathrm{r}=0,297, \mathrm{p}=0,00)$ dan selfcompassion berkontribusi $8,8 \%$ terhadap hope of success $\left(\mathrm{R}^{2}=0,088, \mathrm{~F}=28,857, \mathrm{p}=0,00\right)$, sedangkan self-compassion dan fear of failure memiliki korelasi negatif $(\mathrm{r}=-0,508, \mathrm{p}=0,00)$. Selfcompassion berkontribusi $25,8 \%$ terhadap fear of failure $\left(\mathrm{R}^{2}=0,258, F=8,0060, \mathrm{p}=0,00\right)$.

Kata kunci: self-compassion, hope of success, fear of failure, remaja, bulu tangkis
\end{abstract}

\section{PENDAHULUAN}

Bulutangkis merupakan salah satu olahraga terpopuler di Indonesia. Cabang olahraga ini menjadi populer karena telah memberikan prestasi yang gemilang bagi Indonesia. Berdasarkan hasil penyelenggaraan turnamen olahraga paling bergengsi, yakni Olimpiade, bulu tangkis merupakan cabang olahraga yang paling banyak memberikan medali bagi Indonesia, yakni sebanyak 19 medali (Ministry of Youth and Sports Republic of Indonesia, 2015). Selain Olimpiade, bulu tangkis Indonesia juga berprestasi di ajang turnamen seperti Badminton World Federation (BWF) dan Piala Thomas. Telah tercatat bahwa bahwa Indonesia telah meraih 22 gelar di Kejuaraan Dunia BWF dan 13 kali juara Thomas Cup.

Prestasi Indonesia dalam kancah BWF diperoleh sejak 1977-2018 (Tiongkok Dan Indonesia, Dua Negara Yang Paling Sering Memenangi Kejuaraan Dunia BWF, 2018), Sedangkan pada Thomas Cup, Indonesia berhasil memperoleh gelar juara sejak tahun 1965-2002 (Diah, 2016). Pada ajang turnamen bulu tangkis bergengsi lainnya seperti All
England, atlet Indonesia kembali berhasil mendaptkan prestasi yang membanggakan, seperti Rudy Hartono, yang berhasil menjuarai turnamen All England selama 7 tahun berturut-turut di partai tunggal putra (Jaya, 2017). Hingga saat ini belum ada atlet dari negara lain yang berhasil menyaingi jumlah gelar juara tersebut.

Prestasi yang dicapai, pada dasarnya banyak diraih oleh atlet-atlet di era 1960-2000. Pada tahun 2000 ke atas, prestasi Indonesia cenderung menurun. Titik terendah prestasi bulu tangkis terjadi pada saat penyisihan Piala Thomas tahun 2006 (Adisasmito, 2007). Pada penyelenggaraan pertandingan tersebut, tim Thomas Indonesia tidak berhasil mempertahankan gelar juara. Padahal pada penyelanggaraan tahun-tahun sebelumnya, Indonesia mampu meraih gelar juara sebanyak lima kali berturuturut dari tahun 1994-2002. Penurunan prestasi tersebut dapat disebabkan oleh beberapa faktor, salah satunya adalah faktor psikologis. Scroeter dan Bauersfeld menyatakan bahwa faktor psikologis seperti motivasi juga berperan penting dalam prestasi atlet (Anggraeni, 2013). Tokoh olahraga nasional, MF Siregar, menyatakan bahwa 
penyebab utama penurunan prestasi atlet bulutangkis adalah faktor psikologis, seperti rendahnya motivasi berprestasi (Adisasmito, 2007). Soerjoatmodjo, Moningka, \& Angkawijaya, (2017); Soerjoatmodjo et al., (2017) juga menjelaskan bahwa soft skill termasuk motivasi dan bagaimana cara mengelola emosi merupakan hal yang sangat penting dalam kehidupan atlet. Anggraeni (2013) dalam penelitiannya juga mengemukakan pentingnya soft skill, termasuk emotional intelligence supaya atlet dapat berprestasi dengan baik.

Seiring berjalannya waktu, Banyak klub bulutangkis di Indonesia yang menyadari pentingnya soft skill bagi para atletnya. Mereka memberikan berbagai pelatihan untuk meningkatkan ketahanan mental (mental endurance) para atletnya termasuk meningkatkan motivasi (PB Djarum Asah Mental Atlet Lewat Outbound, 2018).Penelitian ini didasari akan pentingnya soft skills bagi para atlet.

Penelitian berhubungan dengan soft skill yang juga menjadi acuan penelitian ini adalah penelitian Putri, Moningka, Soerjoatmodjo (2018) yang mengidentifikasi adanya hubungan soft skill, yaitu self-compassion dan harapan untuk sukses, sekaligus menghindari ketakutan untuk gagal pada atlet bulu tangkis. Pada penelitian ini, belum diidentifikasi kontribusi soft skill tersebut. Pentingnya peningkatan soft skill atlet dan bagaimana dampaknya bagi atlet memang dirasakan. Pada tahun 2019-2020, para atlet bulu tangkis Indonesia mulai menunjukkan prestasi mereka kambali. Bahkan pada tahun 2020, atlet bulu tangkis Indonesia memperoleh 12 kemenangan dari 7 turnamen (Puspa, 2020). Peningkatan prestasi tersebut bisa jadi tidak terlepas dari berbagai intervensi yang dilakukan pada para atlet untuk membangun mental juara dan meningkatkan motivasi berprestasi.

Motivasi dapat didefinisikan sebagai kekuatan dalam diri individu yang mendorong individu untuk memenuhi kebutuhan atau tujuan tertentu (Yorks dalam Pardee, 1990). Salah satu kebutuhan yang ingin dipenuhi dalam diri manusia adalah kebutuhan untuk berprestasi. Kekuatan dalam diri individu yang mendorongnya untuk memenuhi kebutuhan tersebut adalah motivasi berprestasi. Atkinson (1964) menyatakan bahwa motivasi berprestasi dapat dilihat dari kecenderungan individu untuk mendekati kesuksesan dan kecenderungan untuk menghindari kegagalan. Individu yang memiliki motivasi berprestasi, akan terdorong untuk mencapai kesuksesan dan kerap menghindari kegagalan. (Lang \& Fries, 2006) memberikan istilah hope of success untuk individu yang memiliki kecenderungan untuk meraih kesuksesan dan fear of failure untuk individu yang memiliki kecenderungan untuk menghindari kegagalan. Hope of success membuat atlet memiliki energi untuk meraih kesuksesan meskipun individu juga menyadari bahwa akan ada kegagalan. Dengan memiliki tingkat fear of failure yang rendah, atlet dapat menunjukkan performa maksimal mereka karena dapat bermain tanpa rasa cemas dan takut berlebihan.

Pendapat yang sama dikemukakan oleh, Sagar et al., (2009) yang menjelaskan bahwa fear of failure yang tinggi dapat mempengaruhi kinerja atlet, dimana kecemasan dan rasa takut mengecewakan pelatih atau pihak lain dapat membuat atlet kurang percaya diri akan kemampuannya. Bertanding dengan kurang percaya diri akan membuat atlet mengalami kekalahan. Kekalahan tersebut dapat membuat atlet bertambah tidak bahagia, bahkan depresi. Hal ini juga dapat terjadi karena adanya fear of failure yang semakin dirasakan setiap kali mengalami kekalahan (Sagar et al., 2009).

Hasil penelitian yang dilakukan oleh Soerjoatmodjo et al. (2017) terhadap atlet bulu tangkis di salah satu klub ternama di Indonesia menunjukkan lebih dari 50\% atlet merespons kekalahan dengan hal yang negatif. Contoh respons negatif dari atlet termasuk penolakan (penyangkalan), kesedihan, frustasi, perasaan kalah, kecewa, stress, takut, merasa gagal, dan malu. Mereka juga cenderung ingin menyendiri dan menyerah. Temuan ini juga menunjukkan bahwa saat mengalami kekalahan, banyak atlet yang tidak dapat memahami keadaan diri termasuk tidak memiliki aspek self-compassion.

Neff (2003) menjelaskan bahwa selfcompassion merupakan kecenderungan individu untuk memiliki tiga komponen dalam kehidupannya. Tiga komponen tersebut adalah self-kindness atau perasaan peduli dan pengertian terhadap diri sendiri ketika dihadapkan pada situasi sulit. Komponen ke-2 adalah common humanity yaitu pandangan individu bahwa situasi yang tidak menyenangkan dapat dialami oleh semua manusia atau tidak hanya terjadi pada diri sendiri, dan yang ke-3 adalah mindfulness yaitu bagaimana individu dapat mengambil makna atau pelajaran dari situasi yang sulit. Memaknai penderitaan atau tantangan pada dasarnya adalah ha yang tidak mudah. Hal ini juga dijelaskan pada penelitian Rey dan Moningka, (2013) mengenai pemaknaan self-compassion dimana responden merasa kesulitan untuk mindful.

Pada dasarnya setiap orang tidak terkecuali atlet seharusnya memiliki self-compassion. Selfcompassion pada individu membuat individu memahami bahwa kegagalan atau tantangan yang dihadapi pada dasarnya dihadapi oleh semua orang. Seorang atlet yang memiliki self-compassion dapat menenangkan dirinya seperti ia menenangkan orang lain saat dihadapkan pada situasi yang tidak menyenangkan. Sedangkan individu yang cenderung keras pada diri sendiri saat menghadapi kegagalan, akan cenderung sulit memaknai hal tersebut. Mereka beranggapan bahwa hanya mereka yang menderita atau bahkan tidak menerima kegagalan tersebut sebagai suatu hal yang bisa terjadi pada siapa saja. Individu ini juga cenderung menyangkal atau merepresikan rasa penderitaannya. Mosewich et al. (2013) menyatakan bahwa self-compassion dapat 
berperan penting dalam proses pengelolaan emosi dan dapat menjadi strategi untuk mengatasi pikiran dan emosi negatif terkait kegagalan atau kejadian negatif yang dialami oleh individu, termasuk atlet.

Berdasarkan pernyataan sebelumnya, telah dijelaskan bahwa self-compassion dan hope of success merupakan hal yang penting untuk dimiliki individu, termasuk atlet. Sebagai seorang atlet yang sering dihadapkan dengan banyak kompetisi dan tuntutan untuk berprestasi, individu perlu mengendalikan pikiran dan emosinya ketika menghadapi situasi yang tidak menyenangkan. Selain itu, ketika atlet mengalami kekalahan, diharapkan tetap termotivasi untuk berprestasi dengan melakukan upaya yang dapat mendekatkan dirinya pada kesuksesan (hope of success) dan diharapkan memiliki fear of failure yang rendah.

Penjelasan terkait pentingnya selfcompassion dan dua aspek motivasi berprestasi membuat peneliti tertarik untuk mengetahui kontribusi self-compassion terhadap motivasi berprestasi. Diharapkan penelitian ini juga dapat menjadi landasan untuk meningkatkan prestasi atlet di Indonesia.

\section{METODE PENELITIAN}

Penelitian ini menggunakan metode kuantitatif dengan teknik analisis data regresi linear. Analisis regresi bertujuan untuk mengetahui kontribusi self-compassion terhadap motivasi berprestasi. Responden penelitian ini merupakan anggota aktif di klub bulu tangkis di Jakarta dan memang bertujuan menjadi atlet. Dengan usia 12-17 tahun. Jumlah responden pada penelitian ini berjumlah 85 orang.

Penelitian ini menggunakan skala likert. Skala self-compassion yang digunakan dalam penelitian ini dikembangkan oleh Neff (2003). Skala ini terdiri dari 26 item yang terdiri dari tiga dimensi self-compassion, yakni self-kindness, common humanity dan mindfulness. Peneliti mengadopsi skala ini ke dalam Bahasa Indonesia dan peneliti juga melakukan back forward translation. Koefisien reliabilitas pada skala ini adalah 0,807 dengan menggunakan teknik Cronbach Alpha. Sedangkan skor corrected item-total correlation pada skala ini berkisar antara 0,260-0,549. Peneliti hanya menggunakan 20 item yang memiliki skor corrected item-total correlation di atas 0,30 . Total item pada skala self-compassion yang digunakan pada penelitian ini adalah 20 item.

Skala motivasi berprestasi yang digunakan dalam penelitian ini dikembangkan oleh Lang \& Fries (2006). Skala ini mengukur dua dimensi motivasi berprestasi, hope of success dan fear of failure. Setiap dimensi terdiri dari lima item. Koefisien reliabilitas pada dimensi hope of success adalah 0,653 dengan menggunakan teknik Cronbach Alpha dan skor corrected item-total correlation pada skala ini berkisar antara 0,317-0,479. Koefisien reliabilitas pada skala fear of failure adalah 0,723 dengan teknik Cronbach Alpha. Sedangkan skor corrected item-total correlation pada skala ini berkisar antara 0,400-0,550. Hasil tersebut menunjukkan bahwa skala selfcompassion dan motivasi berprestasi memiliki reliabilitas yang baik.

\section{PEMBAHASAN}

Responden pada penelitian ini merupakan remaja yang aktif di klub dan memiliki intensi menjadi atlet bulutangkis, sberusia 12-18 tahun, dimana sebanyak $42(49,41 \%)$ responden berjenis kelamin laki-laki dan $43(50,59 \%)$ responden berjenis kelamin perempuan. Berdasarkan pengalaman kekalahan dalam sebuah pertandingan, semua responden penelitian mengakui bahwa mereka semua pernah mengalami kekalahan dalam pertandingan. Sedangkan untuk variabel penelitian, responden penelitian dibagi berdasarkan skor self-compassion yang tinggi dan rendah, begitu pula dengan hope of success dan fear of failure. Perhitungan skor tinggi dan rendah didasarkan pada skor rata-rata empiris pada setiap variabel. Nilai rata-rata empiris dari selfcompassion yakni sebesar 67,34, hope of success sebesar 16,89 dan fear of failure sebesar 12,94. Skor responden yang berada di atas nilai rata-rata empiris termasuk dalam kategori tinggi dan skor yang berada di bawah nilai rata-rata empiris termasuk dalam kategori rendah.

Uji asumsi yang digunakan dalam penelitian ini adalah uji normalitas. Hasil uji normalitas pada variabel self-compassion menghasilkan nilai signifikansi $(\mathrm{p}=0,084, \mathrm{p}>0,05)$ yang berarti data berdistribusi normal. Variabel hope of success dan fear of failure juga terdistribusi normal $(\mathrm{p}=0,343$, $\mathrm{p}>0,05)$. Berdasarkan hasil uji normalitas regresi linear dapat dilakukan. Tabel 1 menunjukkan hasil regresi.

Tabel 1. Regresi antara self-compassion dengan Hope of Success dan Fear of Failure

\begin{tabular}{ccccccc}
\hline \multirow{2}{*}{ Variables } & \multicolumn{3}{c}{$\begin{array}{c}\text { Hope of } \\
\text { success }\end{array}$} & \multicolumn{3}{c}{ Fear of failure } \\
\cline { 2 - 6 } & $\mathrm{r}$ & $\mathrm{R}^{2}$ & $\mathrm{r}$ & $\mathrm{R}^{2}$ & $\mathrm{p}$ \\
$\begin{array}{c}\text { Self- } \\
\text { compassion }\end{array}$ & 0,297 & .088 & -0.508 & 0.258 & 0,00 \\
\hline
\end{tabular}


Tabel 1 menunjukkan hasil regresi antara variabel self-compassion dan dua dimensi motivasi berprestasi, yakni hope of success dan fear of failure. Berdasarkan hasil analisis data menggunakan SPSS 25.0 terdapat korelasi positif antara self-compassion dengan hope of success $(\mathrm{r}=0,297, \mathrm{p}=0,00)$. Dengan demikian, dapat dikatakan bahwa dengan meningkatnya kemampuan self-compassion maka akan meningkat harapan individu untuk sukses (hope of success). Berdasarkan perhitungan regresi yang dilakukan, kontribusi variabel self-compassion terhadap hope of success adalah sebesar 8,8\%. Hal ini menunjukkan bahwa $91,2 \%$ hope of success disebabkan oleh faktor lain $\left(\mathrm{R}^{2}=0,088, \mathrm{~F}=28,857\right.$, $\mathrm{p}<0,05)$, seperti self-efficacy, kemampuan teknis ataupun hal lain yang dapat diteliti kembali.

Hasil korelasi self-compassion dengan fear of failure menunjukkan korelasi negatif $(r=-0,508$, $\mathrm{p}=0,00)$. Hasil ini menunjukkan bahwa ada hubungan negatif yang signifikan antara selfcompassion dan fear of failure, dimana apaabila selfcompassion meningkat maka fear of failure akan menurun. Kontribusi variabel self-compassion terhadap fear of failure sebesar $25,8 \%\left(\mathrm{R}^{2}=0,258, \mathrm{~F}=\right.$ $8,006, \mathrm{p}<0,05)$. Dalam penelitian ini, self-compassion merupakan prediktor yang baik terhadap fear of failure dibandingkan prediktor terhadap hope of success. Temuan ini sesuai dengan pernyataan dari Neff et al., (2005) yang menyatakan bahwa selfcompassion berfokus pada sikap emosional individu terhadap pengalaman gagal atau penderitaan, daripada perasaan berharga. Hal ini menunjukkan bahwa selfcompassion memang dibutuhkan ketika individu mengalami kegagalan. Jika individu sudah memiliki harapan, emosi positif, dan percaya diri, maka selfcompassion tidak terlalu berperan.

Hasil penelitian ini juga menunjukkan bahwa self-compassion memiliki peran penting di bidang olahraga. Mosewich et al., (2013) menyatakan bahwa self-compassion merupakan hal penting dalam dunia olahraga. Penelitiannya menunjukkan pentingnya self-compassion dan mmberikan bukti empiris bahwa self-compassion dapat muncul melalui pelatihan, antara lain dengan melakukan psikoedukasi dan pelatihan menulis. Dalam hal ini atlet diminta menuliskan tantangan yang akan dihadapi selama bertanding dan apa saja yang bisa mereka lakukan. Atlet juga diminta untuk melakukan evaluasi diri, apa saja yang telah mereka usahakan untuk bisa bertanding dengan optimal. Leary, (2004) menjelaskan bahwa emosi tertentu dapat muncul dari evaluasi diri dan evaluasi orang lain. Penelitian Mosewich et al., (2013) juga membuktikan bahwa intervensi self-compassion dapat membantu menurunkan emosi negatif terkait dengan citra atau kondisi tubuh pada atlet wanita. Penurunan emosi negatif tersebut akan membantu meningkatkan performa olahraga mereka. Hal ini juga sesuai dengan hasil penelitian Soerjoatmodjo et al., (2017) mengenai soft skill yang dibutuhkan oleh atlet bulutangkis pada salah satu klub bulu tangkis di Indonesia.

Dalam penelitian ini skor empiris untuk variabel self-compassion lebih tinggi dari skor teoritis. Skor tersebut menunjukkan bahwa atlet dalam penelitian ini memiliki self-compassion yang tinggi. Atlet pada penelitian ini memiliki hope of success dan fear of failure yang cenderung tinggi. Hal ini dapat disebabkan oleh faktor budaya di Indonesia pada khususnya dan Asia pada umumnya.

Asia Timur memiliki budaya kolektif. Budaya ini telah diberikan label sebagai masyarakat yang didasarkan rasa malu (shame-based societies). Dalam budaya ini, jika individu mengalami kegagalan maka rasa malu yang muncul tidak hanya dirasakan oleh dirinya tetapi juga dirasakan oleh seluruh keluarga (Peters \& Stefanek, 2012). Terdapat kecenderungan untuk melakukan kritisi diri dalam budaya timur. Masyarakat pada budaya ini dituntut untuk bertanggung jawab atas apa yang mereka lakukan dan karena apa yang mereka lakukan juga mempengaruhi nama baik keluarga, oleh karena itu mereka lebih memiliki fear of failure dibandingkan individu dari budaya individualis. Pada budaya individualis, individu lebih menghargai pencapaian dan usaha mereka. Hal ini sangat penting dimiliki ketika menghadapi berbagai kendala atau kegagalan.

\section{KESIMPULAN}

Analisis data penelitian menghasilkan kesimpulan bahwa terdapat kontribusi selfcompassion dengan dua dimensi motivasi berprestasi, yakni hope of success dan fear offailure. Berdasarkan hasil tersebut dapat disimpulkan bahwa atlet yang memiliki self-compassion yang cenderung tinggi juga memiliki hope of success yang cenderung tinggi. Dengan kata lain, ketika seorang atlet memiliki kepedulian terhadap dirinya sendiri ketika berada dalam situasi yang sulit, dia juga memiliki keinginan atau dorongan untuk meraih kesuksesan. Sementara atlet yang keras terhadap dirinya sendiri saat berada dalam situasi sulit, mereka juga cenderung memiliki rasa takut yang lebih tinggi untuk gagal.

\section{SARAN}

Penelitian yang telah dilakukan menunjukkan kontribusi self-compassion terhadap motivasi berprestasi pada responden. Diharapkan hasil penelitian ini dapat dijadikan dasar oleh manajemen klub atau pelatih untuk mengembangkan intervensi terkait pentingnya self-compassion dalam kehidupan atlet atau calon atlet.

Saran lain yang dapat diberikan adalah supaya manajemen klub dan pelatih dapat memberikan sesi konseling bagi atlet dengan fear of failure yang tinggi. Konseling tersebut diharapkan dapat membantu atlet untuk mengontrol rasa takut terhadap kegagalan. Psikoedukasi berkenaan dengan self-compassion juga perlu dilakukan. Mosewich et al. (2013) berdasarkan hasil penelitiannya berkaitan dengan atlet dan pembentukan self-compassion, 
menjelaskan bahwa psikoedukasi dan pelatihan selfcompassion pada atlet akan membentuk mental yang lebih kuat untuk mengahadapi berbagai tantangan dalam olahraga.

Saran bagi peneliti selanjutnya adalah perlu dilakukan penelitian dengan responden yang lebih luas dan cabang olahraga yang berbeda. Selain itu, peneliti selanjutnya diharapkan mampu menguji kontribusi self-compassion terhadap hope of success dan fear of failure dalam budaya lain.

\section{DAFTAR PUSTAKA}

Adisasmito, L. S. (2007). Mental juara modal atlet berprestasi. PT. Raja Grafindo Persada.

Anggraeni, Y. (2013). Kontribusi IQ (intelligent quotient) dan EQ (emotional quotient) terhadap prestasi atlet pelatda pencak silat pada pon keXVIII tahun 2012. Jurnal Phederal Penjas, $1(1)$, http://www.jurnal.fkip.uns.ac.id/index.php/pen jaskesrek/article/viewFile/958/613

Atkinson, J. W. (1964). An introduction to motivation. Van Nostrand.

Diah, F. (2016). Indonesia paling sering juara piala Thomas, China kedua. https://sport.detik.com/raket/3209110/indonesi a-paling-sering-juara-piala-thomas-chinakedua

Jaya, E. E. (2017). Daftar pebulu tangkis juara all England dari Indonesia. http://olahraga.kompas.com/read/2017/03/07/1 9215371/daftar.pebulu.tangkis.juara.all.englan d.dari.indonesia

Lang, J. W. B., \& Fries, S. (2006). A revised 10-item version of the achievement motives scale psychometric properties in german-speaking samples. European. Psychological Assessment, 22, 216-224.

Leary, M. R. (2004). The fundamental nature of "selfconscious" emotions. Psychological Inquiry, $15,129-131$.

Ministry of Youth and Sports Republic of Indonesia. (2015). Penyajian data dan informasi kepemudaan dan keolahragaan 2014. http://www.kemenpora.go.id/index/preview/sta tistik/10417\%0A\%0A

Rey, Moningka, C. (2013). Pemaknaan Self Compassion Pada Tenaga Kesehatan Di Jakarta Utara Melalui Pendekatan Psikologi Ulayat. 6(2), 29-43.

Mosewich, A. D., Crocker, P. R. E., Kowalski, K. C., \& DeLongis, A. (2013). Applying selfcompassion in sport: An intervention with women athletes. Journal of Sport and Exercise Psychology, 35(5), 514-524. https://doi.org/10.1123/jsep.35.5.514

Neff, K. D. (2003). The Development and Validation of a Scale to Measure Self-Compassionitle. Self and Identity, 2(3), 223-250. https://doi.org/10.1080/15298860309027

Neff, K. D., Hsieh, Y.-P., \& Dejitterat, K. (2005). Self-compassion, Achievement Goals, and Coping with Academic Failure. Self and Identity, 4(3), 263-287. https://doi.org/10.1080/13576500444000317

Pardee, R. L. (1990). Motivation Theories of Maslow, Herzberg, McGregor \&McClelland. A Literature Review of Selected TheoriesDealing with Job Satisfaction and Motivation. https://files.eric.ed.gov/fulltext/ED316767.pdf

PB Djarum Asah Mental Atlet lewat Outbound. (2018). Media Indonesia. https://mediaindonesia.com/olahraga/145921/p b-djarum-asah-mental-atlet-lewat-outbound

Peters, H. J., \& Stefanek, K. A. (2012). Fear of failure: What's culture got to do with it. Athletic Insight's Writings in Sport Psychology, March, 289-299.

Puspa, F. (2020). Prestasi Bulu Tangkis Indonesia, 12 Gelar dari 7 Turnamen Hingga Maret 2020.

Putri, Y.W., Moningka, C., Soerjoatmodjo, G. W. (2018). Hubungan self-compassion dengan Hope of success dan Fear of Failure Pada atlet Remaja Bulu Tangkis di Klub "X". Universitas Pembangunan Jaya.

Sagar, S. S., Lavallee, D., \& Spray, C. M. (2009). Coping with the effects of fear of failure: A preliminary investigation of young elite athletes. Journal of Clinical Sport Psychology, 3(1), 73-98. https://doi.org/10.1123/jcsp.3.1.73

Soerjoatmodjo, G.W.L., Moningka, C., \& Angkawijaya, Y. F. (2017). Layanan konseling bagi atlet jaya raya tahun ke-1 dari rencana 1 tahun.

Soerjoatmodjo, G. W. L., Kaihatu, V., Moningka, C., \& Fransisco, Y. (2017). Prospek Kebutuhan Layanan Psikologis Untuk Atlet Jaya Raya. Widyakala Journal, 4(1), 11. https://doi.org/10.36262/widyakala.v4i1.27

Tiongkok dan Indonesia, dua negara yang paling sering memenangi kejuaraan dunia BWF. (2018). Bobo Id. https://juara.bolasport.com/read/pestaasia/sejar ah/1825795-tiongkok-dan-indonesia-duanegara-yang-paling-sering-memenangikejuaraan-dunia-bwf 